2016

\title{
Ceramic Pipes from Lake Sam Rayburn Caddo Sites, Angelina River Basin, East Texas
}

Timothy K. Perttula

Heritage Research Center, Stephen F. Austin State University

Mark Walters

Heritage Research Center, Stephen F. Austin State University

Follow this and additional works at: https://scholarworks.sfasu.edu/ita

Part of the American Material Culture Commons, Archaeological Anthropology Commons, Environmental Studies Commons, Other American Studies Commons, Other Arts and Humanities Commons, Other History of Art, Architecture, and Archaeology Commons, and the United States History Commons

Tell us how this article helped you.

This Article is brought to you for free and open access by the Center for Regional Heritage Research at SFA ScholarWorks. It has been accepted for inclusion in Index of Texas Archaeology: Open Access Gray Literature from the Lone Star State by an authorized editor of SFA ScholarWorks. For more information, please contact cdsscholarworks@sfasu.edu. 
Ceramic Pipes from Lake Sam Rayburn Caddo Sites, Angelina River Basin, East Texas

\section{Creative Commons License}

\section{(c) (1) (5)}

This work is licensed under a Creative Commons Attribution-NonCommercial 4.0 International License 


\title{
Ceramic Pipes from Lake Sam Rayburn Caddo Sites, Angelina River Basin, East Texas
}

\author{
Timothy K. Perttula and Mark Walters
}

\section{INTRODUCTION}

Ceramic pipes are an important part of the ancestral Caddo material culture in all parts of the Caddo area from as early as ca. A.D. 800, and there are also ceramic pipes known from Woodland period sites in the Caddo area (Hoffman 1967:5, 7). The Caddo pipe forms known include long-stemmed (up to $61 \mathrm{~cm}$ in length) Red River pipes, elbow pipes of several varieties, and platform pipes. All three pipe forms are known from Caddo sites at Lake Sam Rayburn in the Angelina River basin in East Texas (see Jelks 1965).

\section{Lake Sam Rayburn Sites with Pipe Sherds}

Eight different ancestral Caddo sites at Lake Sam Rayburn have grog- or bone-tempered ceramic pipe sherds in their material culture assemblages (Table 1). Most of the pipe sherds are from the Sawmill and Blount sites, and these sites also have the highest proportion of long-stemmed Red River pipe sherds in the various assemblages. These particular sites were likely occupied in ca. A.D. 1000-1400 times, in the Early and Middle Caddo periods (encompassing the early Angelina phase, see Middlebrook [1994, 1997], since long-stemmed pipes were made by Caddo groups as late as ca. A.D. 1400.

Table 1. Pipe sherds from Lake Sam Rayburn Caddo sites in the collections at TARL.

\begin{tabular}{lllll}
\hline Site & $\begin{array}{l}\text { Long-stemmed } \\
\text { pipe }\end{array}$ & $\begin{array}{l}\text { Elbow } \\
\text { pipe }\end{array}$ & $\begin{array}{l}\text { Platform } \\
\text { pipe }\end{array}$ & N \\
\hline Etoile & 1 & 4 & - & 5 \\
Sawmill & 16 & 4 & - & 20 \\
Wylie Price & 1 & 3 & - & 4 \\
McElroy & 2 & 1 & - & 3 \\
Blount & 9 & 1 & - & 10 \\
Brink Powell & - & 1 & - & 1 \\
Print Bell & - & 3 & - & 3 \\
Walter Bell & - & 2 & 1 & 3 \\
\hline Totals & 29 & 19 & 1 & 49 \\
\hline
\end{tabular}

Elbow pipe sherds and platform pipe sherds comprise 40.8 percent of the ceramic pipes in the collections (see Table 1). They are proportionally most common at the Etoile, Wylie Price, Print Bell, and Walter Bell sites, where they occur in Late Caddo period (i.e., late Angelina phase) contexts dating after ca. A.D. 1450-1500.

\section{Etoile Site (41NA11)}

One grog-tempered pipe bowl, probably from an elbow pipe, is decorated with two horizontal engraved lines; the bowl is $5.0 \mathrm{~mm}$ thick and has a $4.0 \mathrm{~cm}$ orifice diameter. There are three other elbow pipe sherds in the assemblage from the Etoile site, all from bone-tempered pipes with flat lips. The first has a segmented bowl (ca. $5.5 \mathrm{~cm}$ in height and $4.0 \mathrm{~cm}$ in orifice diameter) with straight walls, suggesting it may be from 
an L-shaped elbow pipe. The lower portion of one side of the elbow pipe bowl has several diagonal incised lines. The second elbow pipe bowl is plain, with a $4.0 \mathrm{~cm}$ orifice diameter, and the third elbow pipe bowl has a $3.0 \mathrm{~cm}$ orifice diameter.

One grog-tempered pipe sherd from the Etoile site is the conical butt stem end of a long-stemmed Red River pipe, var. Haley (Hoffman 196710 and Figure 5). The sherd (4.2 cm in length) is broken at the attachment of the bowl to the stem.

\section{Sawmill Site (41SA89)}

There are 20 ceramic pipe sherds in the assemblage from the Sawmill site, 16 sherds from long-stemmed Red River style pipes and four sherds from plain elbow pipes. The long-stemmed sherds include bowl rims $(n=6)$ and stems $(n=10) ; 62.5$ percent are from grog-tempered pipes and 37.5 percent are from bone-tempered long-stemmed pipes. The pipe bowl sherds range from 3.9-5.2 $\mathrm{mm}$ in thickness, with a mean of $4.63 \mathrm{~mm}$. The long-stemmed pipe stem sherds have exterior diameters that range from 11.1-14.9 mm, with a mean of $13.03 \mathrm{~mm}$; stem hole diameters range from $3.0-5.1 \mathrm{~mm}$, with a mean of $4.0 \mathrm{~mm}$. These measurements are consistent with the var. Haley form of long-stemmed pipe (Hoffman 1967:10).

The elbow pipe sherds from the site are from both grog-tempered $(n=2)$ and bone-tempered $(n=2)$ pipes. The grog-tempered elbow pipe sherds are plain rims between $5.8-7.7 \mathrm{~mm}$ in thickness. One of the bonetempered pipe sherds is from the juncture of the bowl and stem; it is $7.4 \mathrm{~mm}$ thick. The other bone-tempered elbow pipe sherd is the rim of an L-shaped elbow pipe with a flat lip; the rim is $6.6 \mathrm{~mm}$ in thickness.

\section{Wylie Price Site (41SA94)}

There are sherds from both long-stemmed Red River pipes and elbow pipes in the assemblage from the Wylie Price site. The bone-tempered long-stemmed sherd is from the stem of the pipe; it has a $12.4 \mathrm{~mm}$ exterior diameter and a $4.0 \mathrm{~mm}$ stem hole; this may be from a var. Graves Chapel form of Red River pipe (Hoffman 1967:9). The three elbow pipe sherds from the site are from plain grog-tempered pipes, including a bowl (4.9 mm thick) and two L-shaped elbow pipe rims with flat lips (6.8-8.2 $\mathrm{mm}$ thick); one bowl is circular in shape and the other is rectangular.

\section{McElroy Site (41SA116)}

Two of the three pipe sherds from the McElroy site are from long-stemmed Red River pipes, either grog-tempered or bone-tempered pipes. The bone-tempered sherd is a pipe stem sherd with a $13.9 \mathrm{~mm}$ exterior diameter and a $6.3 \mathrm{~mm}$ diameter, and may be from a var. Haley form of Red River pipe. The grogtempered Red River pipe sherd is a bowl rim that is $3.8 \mathrm{~mm}$ in thickness.

The third pipe sherd from the site is from a bone-tempered elbow pipe bowl. The estimated bowl height is $32.0 \mathrm{~mm}$, with a $34.0 \mathrm{~mm}$ orifice diameter. The pipe bowl is decorated with a horizontal engraved zone filled with vertical hatched lines (Figure 1).

\section{Blount Site (41SA123)}

Nine of the 10 ceramic pipe sherds from the Blount site are from long-stemmed Red River pipes, likely the var. Graves Chapel form. These sherds are from grog-tempered pipes, and include one rounded butt end sherd, four bowl rim sherds (3.9-4.6 $\mathrm{mm}$ in thickness), and four pipe stem sherds. The stem sherds have a mean exterior diameter of $12.08 \mathrm{~mm}$ and mean stem hole diameters of $4.95 \mathrm{~mm}$. 


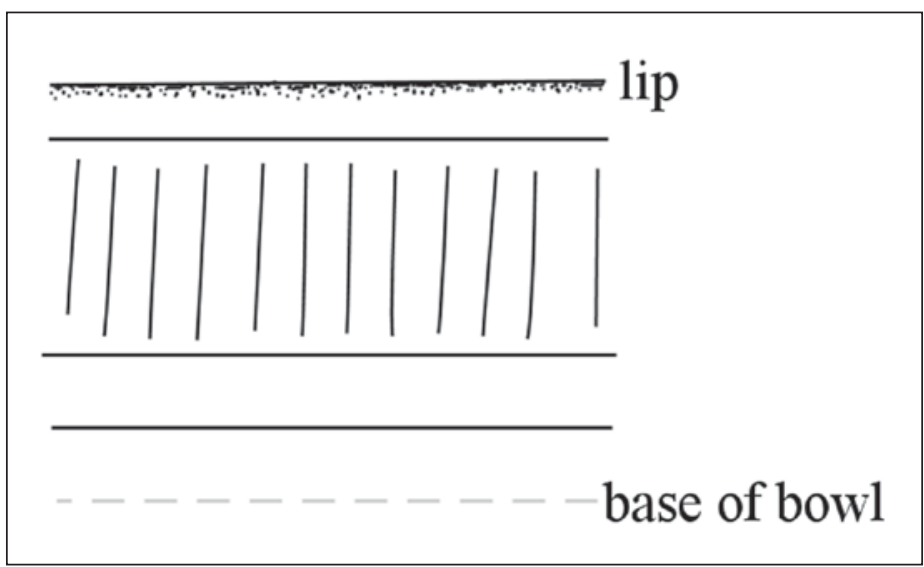

Figure 1. Engraved elbow pipe bowl rim sherd from the McElroy site.

The other pipe sherd is a grog-tempered bowl sherd with a flat base, probably from an L-shaped elbow pipe. There are two concentric engraved semi-circles on the side of the bowl, and a series of diagonal engraved lines on the pipe base (Figure 2).

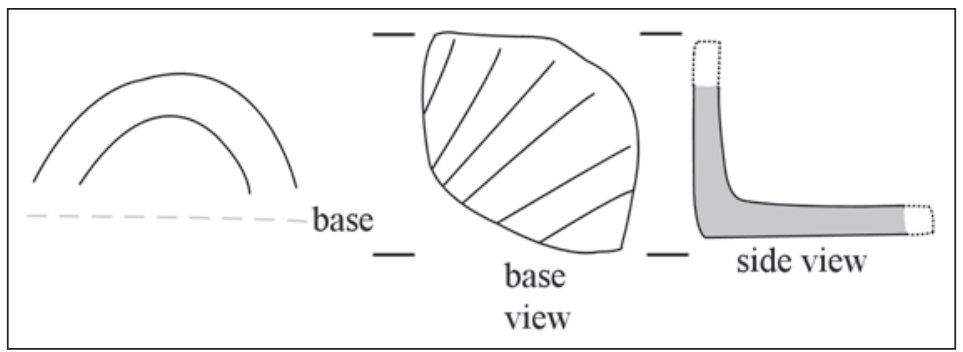

Figure 2. Engraved pipe bowl sherd from the Blount site.

\section{Brink Powell Site (41SB8)}

The one pipe sherd from the Brink Powell site is a grog-tempered and decorated elbow pipe bowl sherd. The bowl has a single horizontal row of very small tool punctations above a series of curvilinear to diagonal engraved lines (Figure 3 ).

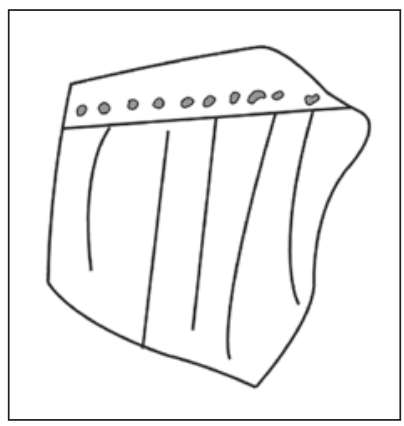

Figure 3. Engravedpunctated elbow bowl rim sherd from the Brink Powell site. 


\section{Print Bell Site (41SB36)}

There are three bone-tempered elbow pipe bowl sherds in the Print Bell site collections. Two are Lshaped elbow pipe forms with flat lips, and the other is a small elbow pipe bowl and stem sherd with engraved and excised decorative elements on the bowl. The bowl is $29.2 \mathrm{~mm}$ in height, with a $14.5 \mathrm{~mm}$ bowl diameter; the stem diameter is $17.0 \mathrm{~mm}$. The engraved-excised motif consists of two narrow horizontal engraved zones filled with hatched lines, with a horizontal engraved line between the zones with downwardpointing excised triangular tick marks (Figure 4). Above the narrow hatched zones are two other horizontal engraved lines, one of which has downward-pointing excised triangular tick marks and the other of which has upward-pointing open pendant triangles.

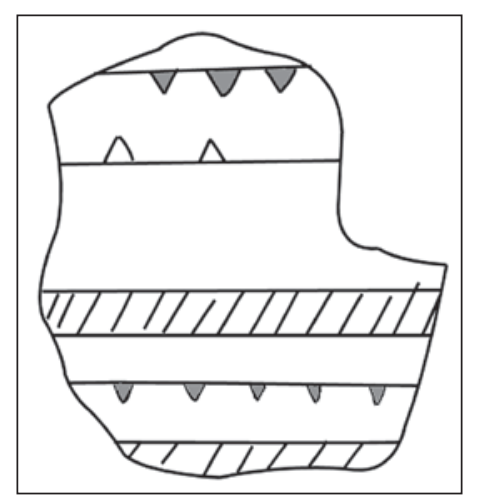

Figure 4. Engraved elbow pipe bowl sherd from the Print Bell site.

Walter Bell Site (41SB50)

The pipe sherds from the Walter Bell site include two rim sherds from elbow pipes and a third sherd from a platform pipe. The bone-tempered platform pipe has a rectangular-shaped base that is $28.6 \mathrm{~mm}$ in length and $24.9 \mathrm{~mm}$ in width with three noded sides (Figure 5). The base of the bowl is centered on the platform. The exterior stem diameter is $21.9 \mathrm{~mm}$, with a $1.4 \mathrm{~mm}$ stem hole.

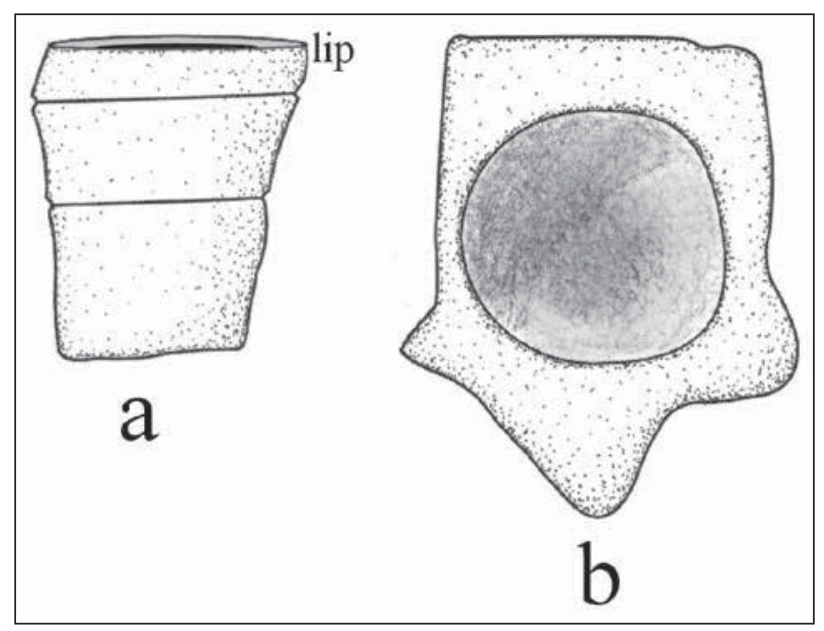

Figure 5. Platform pipe sherd from the Walter Bell site.

The elbow pipe bowl rim sherds are from either grog-tempered or bone-tempered pipes. The grog-tempered pipe sherd ( $7.6 \mathrm{~mm}$ in thickness) is from an L-shaped pipe with a flat lip, while the bone-tempered elbow pipe rim sherd ( $4.9 \mathrm{~mm}$ thick) has two horizontal engraved lines near the lip of the pipe. 


\section{SUMMARY AND CONCLUSIONS}

The ceramic pipe sherds from the Lake Sam Rayburn sites in East Texas indicate that Caddo peoples were smoking tobacco or other native plants for at least 600 years. The earliest pipes were the long-stemmed Red River style pipes with small bowls, which gave way to elbow pipes with short stems and larger bowls in the $14^{\text {th }}$ and $15^{\text {th }}$ centuries A.D. The long-stemmed pipe sherds are from var. Graves Chapel $(\mathrm{n}=10)$ and var. Haley $(\mathrm{n}=18)$ pipes, and one pipe bowl sherd could not be assigned to one of the defined varieties. Most of the long-stemmed pipe sherds are from grog-tempered pipes ( 72 percent).

One form of elbow pipe represented at a few of the sites is the L-shaped elbow pipe ( $\mathrm{n}=7$ sherds or 37 percent of the elbow pipe sherds). Other sites with L-shaped elbow pipes include Oak Hill Village (41RK214), Musgano (41RK19), Lang Pasture (41AN38), Redwine (41SM193), Spoonbill (41WD109), 41SM247, 41SM290, Pace McDonald (41AN51), 41WD244, Joe Smith (41GG50), Wade (in Gregg County), and Beech Ridge (41NA242). These sites, in the Sabine, Neches, and Angelina River basins, have Middle Caddo period occupations, which is when the distinctive L-shaped elbow pipes appear to have begun to be made by Caddo peoples in East Texas. An examination of the clay elbow pipes from mortuary contexts in the upper Neches River basin, from cemeteries of known age, indicates that the earliest elbow pipes are plain L-shaped forms, and are found in contexts estimated to date from ca. A.D. 1320-1450 (Perttula 2014). Later elbow pipe forms, with rounded elbows, and the bone-tempered platform pipe form appear to postdate ca. A.D. 1450.

The elbow pipe sherds from the Lake Sam Rayburn Caddo sites are from both grog-tempered (47 percent) and bone-tempered (53 percent) pipes. A significant proportion of the elbow pipe sherds (including both grog-tempered and bone-tempered sherds) - including one of the L-shaped elbow pipes - are decorated on the bowl or the base (31.6 percent) of certain pipes with engraved horizontal, hatched, or excised tick marks or curvilinear-diagonal engraved and tool punctated decorative elements.

\section{ACKNOWLEDGMENTS}

Lance Trask prepared the figures in this article. We also thank the Texas Archeological Research Laboratory at The University of Texas for access to the collections from the Lake Sam Rayburn sites, and thank Dr. Edward B. Jelks for encouraging our study of the collections.

\section{REFERENCES CITED}

Hoffman, M. P.

1967 Ceramic Pipe Style Chronology Along the Red River Drainage in Southwestern Arkansas. The Arkansas Archeologist 8(1):4-14.

Jelks, E. B.

1965 The Archeology of McGee Bend Reservoir, Texas. Ph.D. dissertation, Department of Anthropology, The University of Texas at Austin.

Middlebrook, T. A.

1994 An Update of Archaeological Investigations at the Tyson Site. Journal of Northeast Texas Archaeology $3: 1-36$.

1997 The Caddoan Occupation of the Attoyac and Angelina River Basins in the Middle Caddoan Period. Journal of Northeast Texas Archaeology 10:36-40.

Perttula, T. K.

2014 The Caddo Archaeology of the Musgano Site (41RK19) in the Sabine River Basin of East Texas. Special Publication No. 28. Friends of Northeast Texas Archaeology, Pittsburg and Austin. 